\title{
Key factors affecting succession in upper montane forest areas of "Planalto Sul Catarinense" Region, Brazil
}

\author{
Factores determinantes de la sucesión de la vegetación en las zonas de alta montaña \\ de la región "Planalto Sul Catarinense", Brasil
}

\author{
Edilaine Duarte a, Pedro Higuchi a*, Ana Carolina da Silva a , Marcos Eduardo Guerra Sobral b, \\ Roseli Lopes da Costa Bortoluzzi ${ }^{\text {a }}$, Jaime Antonio de Almeida a, Janaina Gabriela Larsen ${ }^{\text {a }}$, \\ Juliana Pizutti Dallabrida a , Luran Monteiro Muzeka ${ }^{a}$, Jéssica Thalheimer de Aguiar ${ }^{\text {a }}$, Tarik Cuchi a \\ *Corresponding author: a Universidade do Estado de Santa Catarina, Departamento de Engenharia Florestal, \\ Av. Luiz de Camões, 2090, Lages, Brasil, phone: +55 (49) 32899308, pedro.higuchi@udesc.br. \\ Universidade do Estado de Santa Catarina, Departamento de Engenharia Florestal, Brasil.

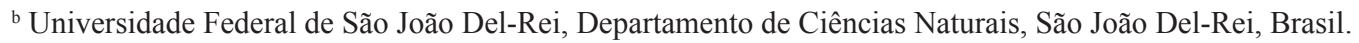

SUMMARY

The understanding of the succession process is a fundamental condition in defining strategies for the conservation and sustainable use of forest ecosystems. Therefore, we aimed at testing which ecological factors affect short-term successional changes in the uppermontane forests of the "Planalto Sul Catarinense" Region, Brazil. We evaluated the influence of propagules source, soil seed bank, edaphic and topographic variables, nucleating elements and natural regeneration floristic-structural composition on demographic rates of tree-shrub regenerating component in three disturbed open vegetation areas at São Joaquim National Park. We inventoried the regenerative component in 2014, 2015 and 2016, within one 20x100 m transect in each area. Afterwards, demographic rates were determined for each period. The influence of explicative variables on demographic rates of the regenerating component was tested through the Generalized Least Square (GLS) model. We found an increment in both individuals and richness over time. When analyzing the influence of the explanatory variables on the speed of the successional process, we observed that only the floristicstructural composition of the natural regeneration was determinant. We conclude that the speed of the represented succession is, to a large extent, a feature related to the phase of the successional trajectory in which the vegetation is found.

Key words: vegetation dynamics, natural regeneration, resilience.

\section{RESUMEN}

Se busca evaluar los factores ecológicos que afectan los cambios sucesionales en los bosques de la alta montaña de la región "Planalto Sul Catarinense", Brasil. Se analizó la influencia de la fuente de propágulos, banco de semillas del suelo, variables edáficas y topográficas, elementos nucleadores y composición florístico-estructural de la regeneración natural en las tasas demográficas del componente de regeneración de árboles y arbustos en tres áreas de vegetación abierta perturbada en el Parque Nacional Nacional de São Joaquim. Se inventarió el componente regenerativo en 2014, 2015 y 2016, dentro de un transecto de 20x100 m en cada área. Entonces, se determinó las tasas demográficas para cada período. La influencia de las variables explicativas en las tasas demográficas del componente de regeneración se evaluó mediante el modelo de mínimos cuadrados generalizados (GLS). Se encontró un incremento tanto en los individuos como en la riqueza a lo largo del tiempo. Al analizar la influencia de las variables explicativas sobre la velocidad del proceso sucesorio, se observó que solo la composición florístico-estructural de la regeneración natural fue determinante. Por lo tanto, se puede inferir que la velocidad de sucesión representa una característica inherente a la fase sucesional de la vegetación. Se concluye que el proceso de sucesión se desarrolló de forma diferente entre áreas, con el pastizal presentando un proceso de invasión leñosa.

Palabras clave: dinámica de la vegetación, regeneración natural, resiliencia.

\section{INTRODUCTION}

Natural vegetation development - i.e., the arrival of new species and changes in the composition, structure and size of populations - is affected by disturbances of variable intensity, frequency and duration (Chazdon 2003,
Chazdon 2012, Meiners et al. 2015). Thus, studies on the process of vegetation dynamics after disturbances are necessary, since they are essential for understanding the regeneration potential of plant communities (Chazdon et al. 2007) and for determining the influence of anthropic disturbances on ecosystems (Meiners et al. 2015). 
The process of vegetation succession, expressed by the floristic and structural changes over time, was one of the major themes of ecological debates in the last century, beginning with the pioneering works of Clements (1916) and Gleason (1926). While Clements understood the vegetation as a single organism and the succession as a deterministic process towards a climax, fundamentally determined by the climate, Gleason saw the vegetation as an element formed from an independent set of species, whose changes along time occurred in a less deterministic way, being influenced by several factors, besides the climate. Some decades later, Connel and Slatyer (1977) suggested an alternative view over the succession mechanisms, showing the possibility of different models, namely facilitation, tolerance and inhibition. According to these authors, the facilitation model involves the colonization of pioneer species, which changes the environment, allowing the arrival of late species. In the tolerance model, the area is colonized at the same time by the initial and late species. In the inhibition model, colonizers prevent other species, thus hindering forest succession.

Today, the consensus is that forest succession is a highly complex process, related to the natural regeneration capacity of the tree component and the disturbance regime (Chazdon et al. 2007), affected by a series of stochastic and deterministic environmental factors (Meiners et al. 2015). Several studies have shown (e.g. Martins et al. 2015) that succession is highly heterogeneous in space, varying according to the disturbance history (regime and recovery time) and environmental factors (e.g. soil, nucleating elements - safe sites for plants - competition, rain, seed bank and sprouting). Similarly, the speed of succession, which is related to the resilience of vegetation, may be variable, occurring slowly in degraded sites (Chazdon 2012). In extreme situations, specific groups of plants or taxons can inhibit this process, as shown by the inhibition model of Connel and Slatyer (1977). In the subtropical part of the Brazilian Atlantic Forest, many studies have been conducted in forests ranging from late-successional areas (e.g. Schorn and Galvão 2009) to early-successional ones (Marcílio-Silva et al. 2016). In the higher parts of the Brazilian southern plateau, where a mosaic of grasslands and forests forms the natural vegetation, studies have shown that nucleating elements (Carlucci et al. 2011a, Dallabrida et al. 2017) and the proximity of the propagules source (Carlucci et al. 2011b) play important roles as succession catalyzers. Besides, it is noteworthy that in this region, there is a process of replacement of the grassland areas by shrub-like vegetation, linked to changes in both the disturbance regime and climate (Müller et al. 2012, Sühs et al. 2020).

Considering that understanding forest succession is critical to assess the human impacts on natural environments, we aimed at testing which factors influence shortterm successional changes in high montane areas in the Southern Plateau of Santa Catarina, Brazil. To this end, we tested the influence of biotic and abiotic variables in three areas that have undergone past anthropogenic impacts relative to i) the propagules source, ii) the soil seed bank, iii) the floristic-structural composition of the regenerating component of the area, iv) environmental variables and v) nucleating elements, on the rates of dynamics of arbustivearboreal regeneration. The selected areas have been protected for approximately ten years and are currently part of the São Joaquim National Park. Two areas were originated from past deforestations of the high montane forest, and one has been a grassland since remote times (see Belhling 2002), although it was impacted by cattle raising for decades. We aimed at answering if those biotic and abiotic variables mentioned above affect the speed of vegetative succession. Due to the long history of degradation in this region, we expect that the seed bank will be represented mostly by ruderal herbaceous species, such that the succession will be positively influenced by the proximity of the propagules sources, by better soils quality, by the presence of nucleating elements and by the characteristics of the regenerating vegetation.

\section{METHODS}

We inventoried three open vegetation areas (Area 1: $28^{\circ} 05^{\prime} 41.5^{\prime \prime} \mathrm{S}, 49^{\circ} 30^{\prime} 14.71^{\prime \prime} \mathrm{W}$, altitude of $1,628 \mathrm{~m}$; Area 2: $28^{\circ} 04^{\prime} 46.87^{\prime \prime} \mathrm{S}, 49^{\circ} 30^{\prime} 51.29^{\prime \prime} \mathrm{W}$, altitude of $1,356 \mathrm{~m}$; Area 3: $28^{\circ} 09^{\prime} 49.19^{\prime \prime} \mathrm{S}, 49^{\circ} 36^{\prime} 47.56^{\prime \prime} \mathrm{W}$, altitude of 1,660 $\mathrm{m})$, next to forest remnants, at the National Park of São Joaquim, in the municipality of Urubici, Santa Catarina, Brazil (figure 1). Areas 1 and 2, originally covered by forests, were deforested around the 60s (area 1) and 80s (area 2) and were kept as pastures until being protected (since 2007 for area 1 and since 2008 for area 2) (Dallabrida et al. 2017). According to the same authors, area 3 was a grassland used for cattle raising since the XIX century and protected since 2008. Therefore, these areas have a long disturbance history and currently are undergoing a post-disturbance recovery process. According to the Brazilian vegetation classification system (IBGE, 2012), the grassland site (Area 3) is classified as "estepes/campos de altitude", which is a relictual vegetation, existent throughout the quaternary, preceding the human presence in the region (Behling 2002).

The natural vegetation is formed by a mosaic of grasslands and upper-montane Araucaria forests. The climate in the region, according to Köppen's classification (Kottek et al. 2006), is $\mathrm{Cfb}$, with annual average temperature of $12.7^{\circ} \mathrm{C}$ and annual average rainfall of $1,753 \mathrm{~mm}$ (Dallabrida et al. 2017).

According to the Brazilian System of Soil Classification (Santos et al. 2013), the soils of the areas are "Neossolos Litólicos" (Leptsols), "Cambissolos Húmicos" (Cambisols), "Nitossolos Brunos Distroférricos" (Nitisols) and "Organossolos Fólicos Sápricos" (Histosols). Leptsols are found at the highest and most steeping parts; Cambisols are predominant in lower slopes. In area 2, deeper soils, 


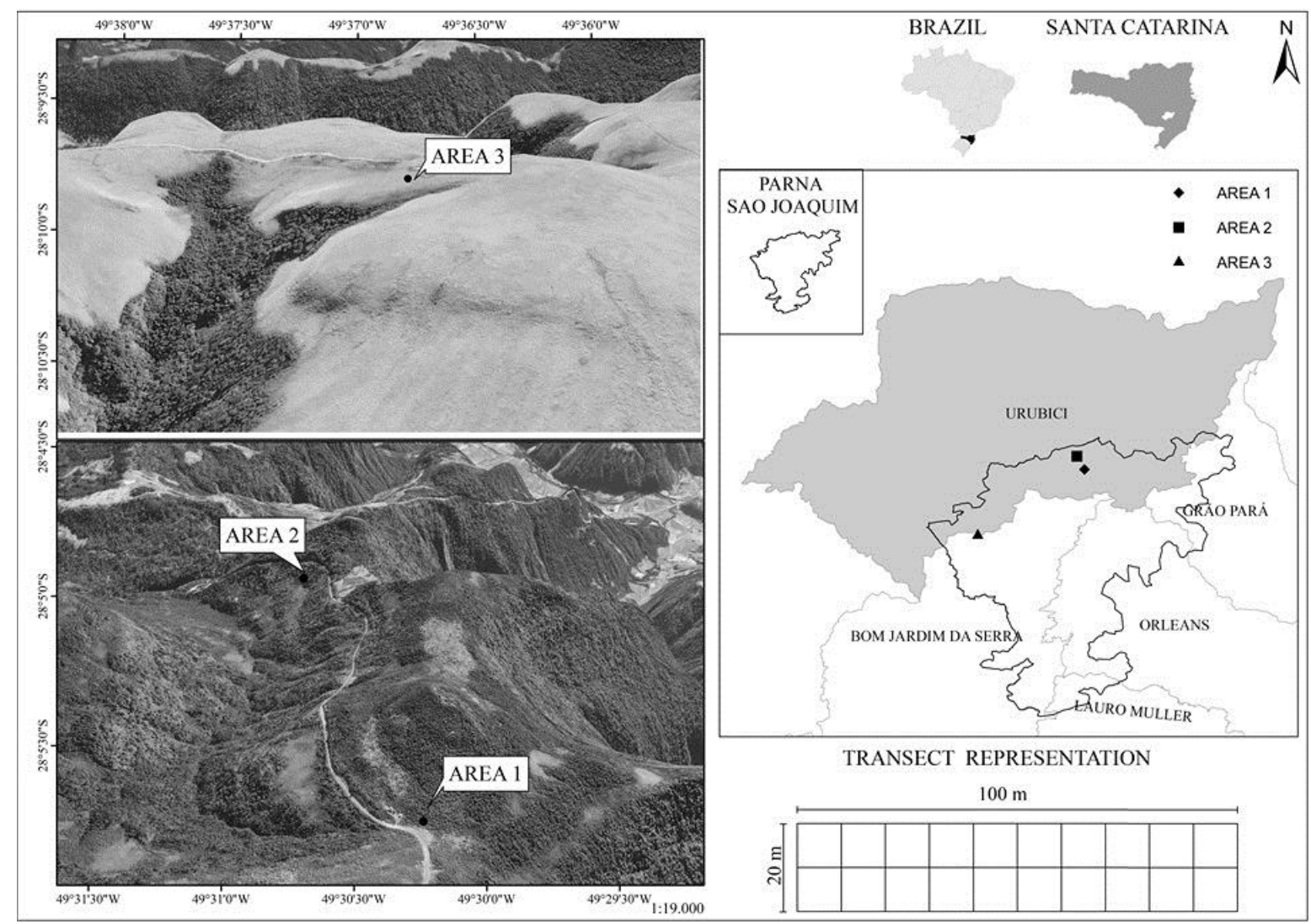

Figure 1. Location of study sites and sampling transect representation in Upper Montane Araucaria Forests, in the municipality of Urubici, Santa Catarina.

Localización de los sitios de estudio y representación de los transectos de muestreo en los Bosques de Araucarias de Alta Montaña, en el municipio de Urubici, Santa Catarina.

such as Nitisols, are frequent in the locations with better natural drainage, and Leptsols with a dark superficial horizon, at those parts close to a watercourse. In area 3, Histosols occur with a black H horizon. The soils of areas 1 and 2 are originated from basalt, and the ones of area 3 from rhyodacite, both from "Serra Geral" formation. Terrain varies from soft wavy to strongly wavy.

The tree-shrub species was surveyed by Dallabrida $\mathrm{et} \mathrm{al}$. (2017) in 2014 and, later, in 2015 (Dallabrida et al. 2019). Three $20 \times 100 \mathrm{~m}$ transects subdivided in $10 \times 10 \mathrm{~m}$ plots were used, totaling $2,000 \mathrm{~m}^{2}$ in each area. These transects were perpendicularly allocated to the fragments edge, with their extension covering the open vegetation area. In 2016, we sampled and tagged all tree-shrub individuals over $1 \mathrm{~m}$ high and under $5 \mathrm{~cm}$ of diameter at breast height (dbh) to determine the demographic rates. The same inclusion level was standardized for all the other years (2014 and 2015) (Dallabrida et al. 2017, 2019). Subsequently, the surviving and dead individuals were counted, and those which reached $1 \mathrm{~m}$ high were recruited. The recruited individuals were identified by specialists and the species classified in families according to the system APG IV (2016).
The rates of recruitment, mortality and abundance net change for the 2014-2015 and 2015-2016 periods were determined and summarized by their average values considering the two periods. Recruitment and mortality rates were obtained by the algebraic models described by Sheil and May (1996): $\mathrm{M}=\left(1-((\mathrm{No}-\mathrm{m}) / \mathrm{No})^{1 / \mathrm{t}}\right) \times 100, \mathrm{R}=(1$ - $\left.(1-\mathrm{r} / \mathrm{Nt})^{1 / t}\right) \times 100$. Where: $\mathrm{M}=$ annual mortality rate $(\%$ year $\left.{ }^{-1}\right), \mathrm{R}=$ annual recruitment rate $\left(\%\right.$ year $\left.^{-1}\right), \mathrm{No}=$ initial number of individuals, $\mathrm{t}=$ time interval between the inventories, $\mathrm{Nt}=$ final number of individuals after $\mathrm{t}, \mathrm{m}=$ number of dead individuals, $r=$ number of recruited individuals. The rates of abundance net change (Chn) were determined by the equation described by Korning and Balslev (1994): $\mathrm{Chn}=\left[(\mathrm{Nt} / \mathrm{No})^{1 / \mathrm{t}}-1\right] \times 100$.

We also determined the rate of floristic-structural (community species composition and abundance) changes over time, according to Collins et al. (2000), though adapted to our data, with a smaller number of time intervals, thus with no testing of slopes significance. For each plot, we determined the slope coefficient of the straight line connecting two points, which represented the temporal floristic-structural similarity for 2014-2015 and 2014-2016. The positi- 
ve values of the slope coefficient show a trend of increasing dissimilarities over time, negative values indicate a tendency of increasing similarities over time, and the slope coefficient equal to zero shows a no changing pattern.

Demographic and floristic-structural change rates were ordered by a Principal Component Analysis (PCA) to identify the main dynamics pattern synthesized by the PCA axis 1 , which explained most of the total inertia. The PCA axis 1 significance was verified by the Scree Plot analysis.

To determine which ecological factors affect PCA axis 1 , we considered the following variables: i) the propagules source, ii) the quality of the seed bank, iii) the floristicstructural composition of the regenerating component, iv) the soil variables and $v$ ) the presence of nucleating elements.

i) The quality of the propagules source was summarized by a synthetic variable related to the floristic-structural composition of the adjacent forest fragment and the distance from each plot to the fragment edge. The tree communities data (trees over $5 \mathrm{~cm}$ of diameter at breast height) obtained from Duarte et al. (2018) were ordered by a Principal Coordinates Analysis (PCoA). We assumed that the ordination of the community data from adjacent forest fragments would summarize the quality of vegetation as a potential propagules source. The quality of the propagule source was considered as the sum of the centroid value of each fragment and the distance of each plot of the regenerative component to the forest fragment edge.

ii) Based on Duarte et al. (non-published data), as the quality of the seed bank, we considered the floristic-structure composition (community species composition and abundance) of the emerging seedlings from the seed bank of each plot (Brown 1992). After a PCoA ordination, the scores of each plot along the PCoA axes 1 and 2 were used as explanatory variables for the dynamics patterns (Dynamics PCA axis 1). Still, to verify which seed bank species were related to axes 1 and 2 of PCoA, we applied a Multivariate Generalized Linear Model, according to Wang et al. (2012), with the negative binomial distribution.

iii) As the structural-floristic composition of the regenerating component, we used the data (community species composition and abundance) obtained by Dallabrida et al. (2017), which were subjected to the same analytical approach described in the previous item (ii);

iv) Soil (physico-chemical properties and compaction) and topographic (altitude, maximum elevation gap and average declivity) variables, obtained for the same plots by Dallabrida et al. (2017), were ordered by the Principal Components Analysis (PCA). The plots scores along PCA axes 1 and 2 were extracted to be used as explanatory variables for the dynamics pattern (Dynamics PCA axis 1); v) Nucleating elements of each plot were considered as the sum of the counting of rocks, dead tree ferns, fallen trunks and adult tree individuals $(\mathrm{dbh} \geq 5 \mathrm{~cm})$ (Dallabrida et al. 2017).

We fitted a linear model by the Generalized Least Square (GLS) method to analyze the influence of the explanatory variables (i, ii, iii, iv, and v) on the dynamics pattern of the regenerative component (Dynamics PCA axis 1). The Dynamics PCA axis 1, which is the one that most explains the total inertia of demographic variables, can be considered as a synthetic variable that summarizes the main gradient of vegetative changes regarding the evaluated plots. This approach allowed to incorporate the heterogeneity of the evaluated variables, such as the spatial variations associated with different areas. Because of presenting a few individuals and empty plots, which would represent a bias in the analysis, area 3 was not included here. The residuals heterogeneity was incorporated into the model by an exponential function of the covariate variance. Significant explanatory variables were selected by the stepwise procedure based on the information criteria of Akaike (AIC) (Venables and Ripley 2002). The final model was validated through the residual analysis. All analyses were performed with R (R Core Team 2019), along with MASS (Venables and Ripley 2002), nlme (Pinheiro et al. 2016), vegan (Oksanen et al. 2016), mvabund (Wang et al. 2012) and codyn (Hallett et al.2020) packages. All data used in the analyses are available in Duarte et al. (2021).

\section{RESULTS}

Structural-floristic composition, dynamics and speed of the succession process. We sampled 761 individuals, distributed in 34 species, 23 genera and 16 families in 2014; 996 individuals, distributed in 35 species, 24 genera and 17 families in $2015 ; 1,160$ individuals, distributed in 38 species, 25 genera and 18 families in 2016 (table 1). The richest families were Myrtaceae, followed by Asteraceae, Lauraceae and Solanaceae. The most expressive genera were Myrcengenia, Baccharis and Solanum. The most abundant species were Baccharis uncinella DC. in area 1, Campovassouria cruciata (Vell.) in area 2 and Baccharis lymanii G.M.Barroso ex G.Heiden in area 3.

In the Principal Components Analysis (PCA) of vegetation dynamics rates, axes 1 and 2 explained $89.45 \%$ of the total inertia, and both were significant according to the Scree Plot analysis (figure 2A). The most correlated variables with axis 1 (figure $2 \mathrm{~B}$ ) - the most explanatory one $(60.34 \%)$ - were the recruitment $(0.61)$, the net change in the number of individuals $(0.54)$ and the structural-floristic change (0.54). While on the left are the most stable plots, predominantly in area 1 , on the right side are the more dynamic plots, mostly in area 2 . Thus, from left to right of axis 1 , there is a gradient of succession speed. 
Table 1. Sampled species in upper montane Araucaria Forest areas, in "Planalto Sul Catarinense" Region, Santa Catarina. N1 = number of individuals in 2014, N2 = number of individuals in 2015 and N3 = number of individuals in 2016. H= registration number at the Lages Herbarium, Santa Catarina State University (LUSC).

Especies muestreadas en áreas de Bosque de Araucarias de alta montaña, en la región "Planalto Sul Catarinense", Santa Catarina. N1 = número de individuos en 2014; N2 = número de individuos en 2015 y N3 = número de individuos en 2016 . H = número de registro en el Herbario Lages, de la Universidad del Estado de Santa Catarina (LUSC).

\begin{tabular}{|c|c|c|c|c|c|c|c|c|c|c|}
\hline \multirow{2}{*}{ Family/ Species } & \multicolumn{3}{|c|}{ Area 1} & \multicolumn{3}{|c|}{ Area 2} & \multicolumn{3}{|c|}{ Area 3} & \multirow[t]{2}{*}{$\mathrm{H}$} \\
\hline & N1 & $\mathrm{N} 2$ & N3 & N1 & $\mathrm{N} 2$ & N3 & N1 & $\mathrm{N} 2$ & $\mathrm{~N} 3$ & \\
\hline \multicolumn{11}{|l|}{ Anacardiaceae } \\
\hline Schinus polygama (Cav.) Cabrera & 2 & 2 & 2 & & & & & & & 8,763 \\
\hline \multicolumn{11}{|l|}{ Aquifoliaceae } \\
\hline Ilex microdonta Reissek & & 1 & 2 & & & & & & & 8,764 \\
\hline \multicolumn{11}{|l|}{ Araucariaceae } \\
\hline Araucaria angustifolia (Bertol.) Kuntze & 2 & 2 & 2 & & & 1 & & & & 8,765 \\
\hline \multicolumn{11}{|l|}{ Asteraceae } \\
\hline Baccharis lymanii G.M.Barroso ex G.Heiden & & & & & & & & & 48 & - \\
\hline Baccharis microdonta DC. & 9 & 9 & 9 & 7 & 20 & 32 & & & & 8,771 \\
\hline Baccharis uncinella DC. & 138 & 154 & 165 & 149 & 161 & 165 & 2 & 2 & 5 & 8,768 \\
\hline Campovassouria bupleurifolia (DC.) R.M. King et H. Rob. & 1 & 1 & 2 & & & & & & & - \\
\hline Campovassouria cruciata (Vell.) R.M.King et H.Rob. & 4 & 3 & 4 & 70 & 150 & 184 & & & & 8,772 \\
\hline Senecio brasiliensis (Spreng.) Less. & & & 2 & 49 & 68 & 20 & & & & 8,766 \\
\hline Symphyopappus itatiayensis (Hieron.) R.M.King et H.Rob. & 17 & 16 & 13 & & & & & & & 8,773 \\
\hline Vernonanthura montevidensis (Spreng.) H.Rob. & 3 & 3 & 3 & 9 & 9 & 9 & & & & 8,770 \\
\hline \multicolumn{11}{|l|}{ Berberidaceae } \\
\hline Berberis laurina Billb. & 10 & 17 & 28 & 18 & 21 & 24 & & & & 8,774 \\
\hline \multicolumn{11}{|l|}{ Celastraceae } \\
\hline Maytenus boaria Molina & 3 & 4 & 6 & & & & & & & 8,775 \\
\hline \multicolumn{11}{|l|}{ Clethraceae } \\
\hline Clethra uleana Sleumer & & & & & & 1 & & & & 8,776 \\
\hline \multicolumn{11}{|l|}{ Escalloniaceae } \\
\hline Escallonia bifida Link et Otto & & & & 2 & 2 & 2 & & & & 8,779 \\
\hline \multicolumn{11}{|l|}{ Euphorbiaceae } \\
\hline Croton cf. patrum L.B.Sm. et Downs & & & & 14 & 10 & 8 & & & & 8,762 \\
\hline \multicolumn{11}{|l|}{ Fabaceae } \\
\hline Mimosa pilulifera Benth. & & & & 1 & 1 & 1 & & & & 8,780 \\
\hline Mimosa scabrella Benth. & & & & 8 & 7 & 5 & & & & - \\
\hline \multicolumn{11}{|l|}{ Lauraceae } \\
\hline Cinnamomum amoenum (Nees et Mart.) Kosterm. & & & & 3 & 6 & 6 & & & & 8,781 \\
\hline Ocotea pulchella (Nees et Mart.) Mez & 5 & 6 & 7 & & & & & & & 8,782 \\
\hline Persea willdenovii Kosterm. & 3 & 5 & 5 & & & & & & & 8,783 \\
\hline \multicolumn{11}{|l|}{ Melastomataceae } \\
\hline Leandra sp. & & & & 1 & 1 & 1 & & & & 8,785 \\
\hline
\end{tabular}


Myrtaceae

Myrceugenia cf. mesomischa (Burret) D.Legrand et Kausel

Myrceugenia euosma (O.Berg) D.Legrand

Myrceugenia glaucescens (Cambess.) D.Legrand et Kausel

Myrceugenia miersiana (Gardner) D.Legrand et Kausel

Myrceugenia myrcioides (Cambess.) O.Berg

Myrceugenia oxysepala (Burret) D.Legrand et Kausel

Myrceugenia pilotantha (Kiaersk.) Landrum

Myrceugenia regnelliana (O.Berg) D.Legrand et Kausel

Siphoneugena reitzii D.Legrand

Primulaceae

Myrsine coriacea (Sw.) R.Br. ex Roem. et Schult.

Scrophulariaceae

Buddleja reitzii E. M. Norman et L. B. Sm.

Solanaceae

Solanum cassioides L.B.Sm. et Downs

Solanum paranense Dusén

Solanum pseudocapsicum L.

Symplocaceae

Symplocos pentandra (Mattos) Occhioni ex Aranha

Winteraceae

Drimys angustifolia Miers

Total

Which factor determines the velocity of vegetative succession?. The ordinations of the explanatory variables on the dynamics of the regenerative component showed that: i) the adjacent forest fragments have structural-floristic differences (figure 3A); ii) the areas have high environmental heterogeneity, with clear gradients of fertility (axis 1 of environmental PCA - figure 3B) and soil compaction (axis 2 of environmental PCA - figure 3B); and iii) both the seed bank (figure $3 \mathrm{C}$ ) and the regenerative component (figure 3D) have high structural-floristic variation.

In the floristic-structural composition of the seed bank (table 2), Galium humile Cham. et Schltdl was associated to positive values of PCoA axis 1 (where most of the plots of area 1 are located); Juncus capillaceus Lam., associated to negative values of PCoA axis 1 (plots of area 2, predominantly) and Digitaria cf. horizontalis Willd., associated to positive values PCoA axis 2. For the regenerative component, $S$. brasiliensis predominated at the plots with positive values in PCoA axis 1 (plots of area 2), Solanum cassioides L.B.Sm. et Downs was associated

\begin{tabular}{|c|c|c|c|c|c|c|c|c|c|}
\hline & 1 & 2 & & & & & & & 8,791 \\
\hline 12 & 17 & 20 & 12 & 15 & 15 & & & & 8,786 \\
\hline 6 & 12 & 24 & 4 & 6 & 10 & & & & 8,794 \\
\hline 1 & 3 & 7 & & & & & & & 8,787 \\
\hline 6 & 6 & 7 & & & & & & & 8,789 \\
\hline 1 & 2 & 6 & 3 & 4 & 4 & & & & 8,790 \\
\hline 2 & 4 & 4 & & & & & & & 8,788 \\
\hline 11 & 20 & 25 & 3 & 6 & 7 & & & & 8,792 \\
\hline 2 & 5 & 7 & 1 & 1 & 1 & & 1 & 1 & 8,793 \\
\hline \multirow[t]{2}{*}{1} & 2 & 2 & 3 & 4 & 8 & & & & 8,795 \\
\hline & & & 2 & 2 & 2 & & & & 8,777 \\
\hline 48 & 60 & 92 & & & & & & & 8,798 \\
\hline \multirow[t]{2}{*}{60} & 72 & 70 & 16 & 32 & 34 & & & & 8,796 \\
\hline & & 2 & 1 & & 1 & & & & 8,797 \\
\hline 4 & 4 & 4 & & & & & & & 8,799 \\
\hline 29 & 33 & 38 & 3 & 3 & 5 & & & & 8,800 \\
\hline 380 & 464 & 560 & 379 & 529 & 546 & 2 & 3 & 54 & \\
\hline
\end{tabular}

with negative values of PCoA axis 1 (plots of area 1); $B$. uncinella, associated with positive values of PCoA axis 2 (plots of area 1 predominantly) and C. cruciata with negative values of PCoA axis 2 (plots of both areas, but where most of the plots of area 2 are located). Therefore, G. humile in the seed bank and S. cassioides, Drimys angustifolia Miers, Symphyopappus itatiayensis (Hieron.) R.M.King et H.Rob and Solanum paranense Dusén in the natural regeneration characterized area 1.J. capillaceus in the seed bank and S. brasiliensis in the natural regeneration marked area 2.

Only the floristic-structural composition of natural regeneration influenced the speed of the successional process (PCoA regenerative axis 1: $P=0.0015$, PCoA regenerative axis $2: P=0.0180$ ) (figures $4 \mathrm{~A}, \mathrm{~B}$; table 3 ). The final model is well adjusted, being suitable for interpretation (figures 4C, D, E, F). The residuals were normally distributed and did not have any trend, showing that the spatial heterogeneity among the areas was well captured by the model (GLS). 
The succession speed presented a positive correlation with axis 1 of PCoA of the natural regeneration (figure 4A) and a negative correlation with axis 2 of the same ordination (figure 4B). Thus, considering the species distribution along the axis of the natural regeneration PCoA (table 2), we can infer that while a faster succession occurred in the sites with higher abundance of $S$. brasiliensis and C. cruciate, a slower one took place in the areas with superior presence of $S$. cassioides, D. angustifolia, $S$. itatiayensis, $S$. paranense and B. uncinella.
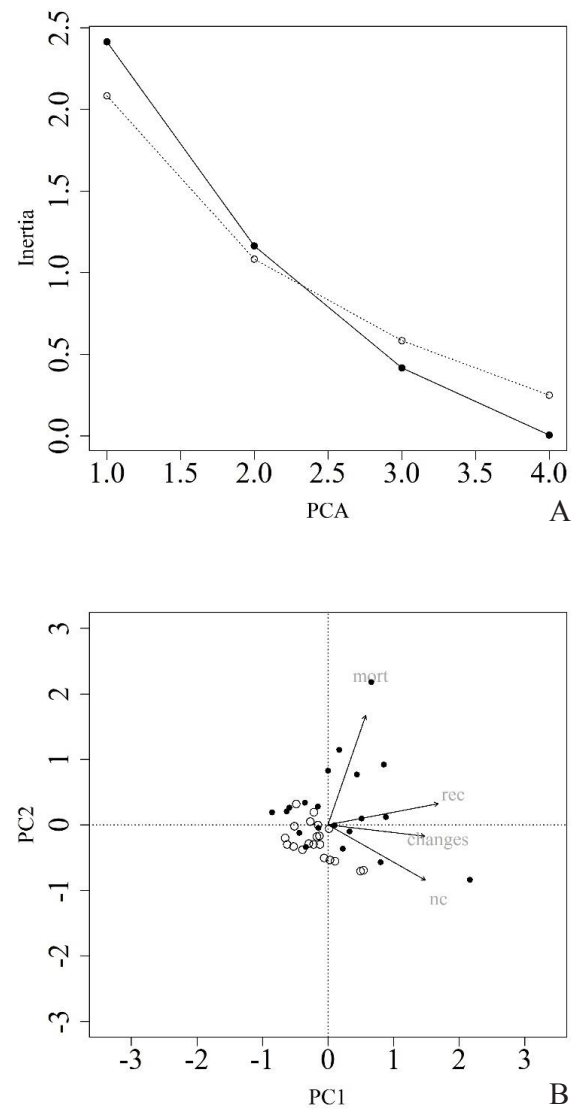

Figure 2. Scree plot (A) (dotted line representing random values determined by the broken stick distribution, continuous line representing values of inertia observed for each ordination axis) and ordination (B) (Empty circles: Area 1, Filled circles: Area 2) of the demographic rates (mort $=$ mortality rate, $\mathrm{rec}=$ recruitment rate, $\mathrm{nc}=$ number of individuals net change) and floristic-structural change rate (changes) from Principal Component Analysis (PCA), in Upper Montane Araucaria Forest areas, in "Planalto Sul Catarinense" Region, in Brazil.

Scree plot (A) (la línea de puntos representa los valores aleatorios estimados con la distribución de "vara rota", la línea continua representa los valores de inercia observados para cada eje de ordenación) y ordenación (B) (Círculos vacíos: área 1, círculos llenos: área 2) de las tasas demográficas (tx mort $=$ tasa de mortalidad; tx rec $=$ tasa de reclutamiento; tx_ml = cambio neto del número de individuos y tasa de cambio florístico-estructural por un Análisis de Componentes Principales (PCA), en áreas de Bosque de Araucarias de Alta Montaña, en "Planalto Sul Catarinense", en Brasil.

\section{DISCUSSION}

After being protected from anthropogenic impacts for about one decade, the evaluated open vegetation areas showed an increase in the number of tree-shrub individuals, thus characterizing an encroachment process. There was also a small increase in species richness from 34 to 38 species. These results support the idea that the structural (abundance) recovery of vegetation occurs at a faster pace than do the changes in the floristic composition and richness. Likewise, as suggested by Chazdon (2003), the low floristic change can be partially explained by the long degradation history. It is noteworthy that our findings have to be interpreted in light of the current study temporal scale (2014-2016), which evaluated short-term changes in areas that have been protected for about a decade.

Shrubs rapidly encroached the natural grassland of area 3. Woody encroachment is a major threat to high-altitude natural grassland areas in southern Brazil, being a process regulated by site conditions and climatic changes (Müller et al. 2012, Sühs et al. 2020). In turn, forest succession is an expected process for past deforested areas (Rocha et al. 2016), and taking into account the limiting environmental conditions in the studied regions (e.g. frosts), the group of pioneer species has an important role in facilitating the succession process (Duarte et al. 2018). We also observed variations in the speed of the vegetational succession process. Thus, as noted for forests in advanced successional stages (e.g. Machado and Oliveira-Filho 2010), the initial recovery process also shows a high spatial heterogeneity, suggesting the complexity of this process.

Similar to the dynamics patterns, the plots also had variations related to biotic and abiotic factors, which were previously discussed in detail by Dallabrida et al. (2017) and Duarte et al. (2018). Despite the high environmental heterogeneity, only the floristic-structural properties of the regenerating component influenced the speed of succession. While faster changes were observed for the plots with the presence of Asteraceae S. brasiliensis and C. cruciata, slower dynamics was associated to the presence of $S$. cassioides, $D$. angustifolia, $S$. itatiayensis, $S$. paranense and $B$. uncinella. The ruderals $S$. brasiliensis and C. cruciate were already reported in degraded areas (Silveira and Maranho 2012), presenting a relatively shorter lifespan. In this sense, we can infer that for our studied areas the speed of the post-disturbance recovery represented a vegetation property inherent to the successional stage in which it is found. The lack of influence of the seed bank in our study reinforces what other studies (Vieira and Overbeck 2020, Silva and Overbeck 2020) have already evaluated for the region regarding this vegetative component quality.

The spatial heterogeneity of the forest succession pattern that we found supports the idea that this complex process (Chazdon 2003, Chazdon 2012, Meiners et al. 2015) mostly expresses the point in time that the vegetation lies along the succession trajectory (Rocha et al. 2016). Rocha 

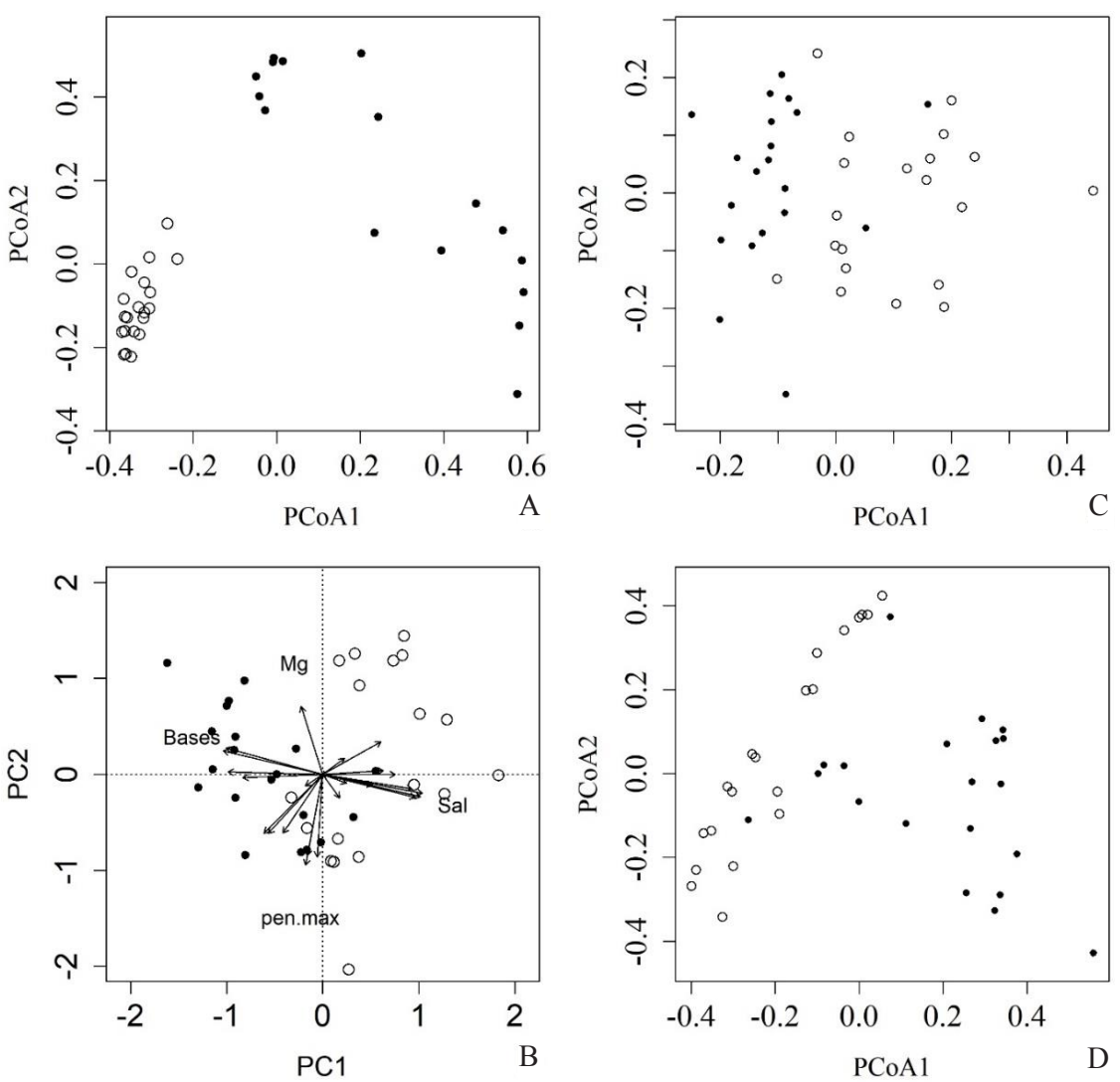

Figure 3. Ordination (Empty circles: Area 1, Filled circles: Area 2) of potentially influential variables on the speed of vegetational succession process in Upper Montane Forests in "Planalto Sul Catarinense" Region, Brazil. (A = PCoA of adult component floristic-structural composition; $\mathrm{B}=$ PCA of the environmental variables, showing those variables with more significant positive and negative correlation on axes 1 and 2 (Sum of Bases, Sal = Aluminum saturation, $\mathrm{Mg}=$ magnesium and pen $\cdot \max =$ soil compaction); $\mathrm{C}=\mathrm{PCoA}$ of seed bank floristic-structural composition and $\mathrm{D}=\mathrm{PCoA}$ of regenerative component floristic-structural composition of 2014 first inventory).

Ordenación de las variables potencialmente influyentes sobre la velocidad del proceso de sucesión vegetacional en los Bosques de Alta Montaña, en "Planalto Sul Catarinense", Brasil (A = PCoA de la composición florística y estructural del componente adulto; B = PCA de las variables ambientales de la composición florística y estructural del componente regenerativo del primer inventario en 2014; C = PCoA de la composición florísticoestructural del banco de semillas e D = PCoA de la composición florística y estructural del componente regenerativo del primer inventario en 2014).

et al. (2016), studying abandoned pastures in the Amazon, observed that the historical use before the abandonment is a determinant factor in the natural regeneration process. Likewise, in subtropical high altitude areas of southern Brazil, the use history and the disturbance regime have been reported as critical factors for natural regeneration (Sühs et al. 2018). It is also noteworthy that, while the influence of nucleating elements, such as nurse plants, has not been reported as significant in this study, it has often been reported as highly important acting as facilitating elements in the initial succession process in southern Brazilian high-altitude areas (Carlucci et al. 2011b, Korndörfer et al. 2015, Marcílio-Silva et al. 2015).

\section{CONCLUSIONS}

About 10 years after protecting the areas, the shortterm succession process presented a high degree of spatial heterogeneity, with recruitment exceeding mortality. Overall, our findings have partially confirmed the initial hypotheses. As we expected, the seed bank did not influence natural regeneration dynamics. Besides, the regeneration taxonomical identity was the only factor that affected the speed of succession, being faster in plots where $S$. brasiliensis and C. cruciata, which are ruderal species with a short lifespan, were abundant. Thus, we can infer that the speed of succession represented is, to a large extent, a feature related to the phase of the successional trajectory in which the vegetation is found.

\section{ACKNOWLEDGEMENTS}

To FAPESC, for granting the scholarship to the first author and the financial support through PAP/UDESC. To $\mathrm{CNPq}$, for the financing by Edital Universal MCTI/CNPq $14 / 2014$ and concession of the productivity scholarship for 
Table 2. Species with significant associations with axes 1 and 2 of the Principal Coordinate Analysis (PCoA), according to the Generalized Linear Multivariate Model, with the negative binomial distribution, for the seed bank and regenerative component in Upper Montane Araucaria Forest, in "Planalto Sul Catarinense" Region, Brazil.

Especies con asociaciones significativas con los ejes 1 y 2 del Análisis de Coordenadas Principales (PCoA), según el Modelo Multivariado Lineal Generalizado, con la distribución binomial negativa, para el banco de semillas y para la regeneración natural en el Bosque de Araucarias de Alta Montaña, en "Planalto Sul Catarinense", Brasil.

\begin{tabular}{|c|c|c|}
\hline Seed bank species & Coefficients & $P$ \\
\hline \multicolumn{3}{|l|}{ AXIS 1 PCoA [figure 3C] } \\
\hline Austroeupatorium inulaefolium (Kunth) R.M.King et H.Rob. & 7.62 & $*$ \\
\hline Baccharis vulneraria Baker & 6.56 & $*$ \\
\hline Dichanthelium sabulorum (Lam.) Gould et C.A. Clark & 5.02 & $*$ \\
\hline Galium humile Cham. et Schltdl. & 8.04 & $* *$ \\
\hline Holcus lanatus L. & 3.28 & $*$ \\
\hline Juncus capillaceus Lam. & -3.69 & $*$ \\
\hline \multicolumn{3}{|l|}{ AXIS 2 PCoA [figure 3C] } \\
\hline Digitaria cf. horizontalis Willd. & 8.28 & $*$ \\
\hline Juncus capillaceus Lam. & 2.85 & $*$ \\
\hline Regenerative component species & Coefficients & $P$ \\
\hline \multicolumn{3}{|l|}{ AXIS 1 PCoA [figure 3D] } \\
\hline Campovassouria cruciata (Vell.) R.M.King et H.Rob. & 3.58 & $* * *$ \\
\hline Drimys angustifolia Miers & -9.45 & $* * *$ \\
\hline Senecio brasiliensis (Spreng.) Less. & 12.86 & $* * *$ \\
\hline Solanum cassioides L.B.Sm. et Downs & -10.43 & $* * *$ \\
\hline Solanum paranense Dusén & -4.78 & $* * *$ \\
\hline Symphyopappus itatiayensis (Hieron.) R.M.King et H.Rob. & -7.40 & $* *$ \\
\hline \multicolumn{3}{|l|}{ AXIS 2 PCoA [figure 3D] } \\
\hline Baccharis uncinella DC. & 2.24 & $* * *$ \\
\hline Campovassouria cruciata (Vell.) R.M.King et H.Rob. & -2.59 & ** \\
\hline
\end{tabular}

Table 3. Generalized Least Square (GLS) model coefficients, with the structure of the heterogeneity of the residue incorporated to the model by an exponential function of the covariate variance, for Upper Montane Araucaria Forest areas, in "Planalto Sul Catarinense" Region, Brazil.

Coeficientes del modelo de mínimos cuadrados generalizados (GLS), con la estructura de la heterogeneidad del residuo incorporado al modelo por una función exponencial de la varianza covariable, para las áreas del Bosque de Araucarias de Alta Montaña, en "Planalto Sul Catarinense", Brasil.

\begin{tabular}{lccc}
\hline & Dynamics pattern (PCA 1 dynamics rates) & Standard error & $P$ \\
\hline Intercept & -0.004103 & 0.0721428 & ns \\
PCoA regenerative axis 1 & 0.9779525 & 0.2851941 & $* *$ \\
PCoA regenerative axis 2 & -0.7969438 & 0.321964 & $* *$ \\
\hline
\end{tabular}

$* *=P<0.01, \mathrm{~ns}=$ non-significative. 

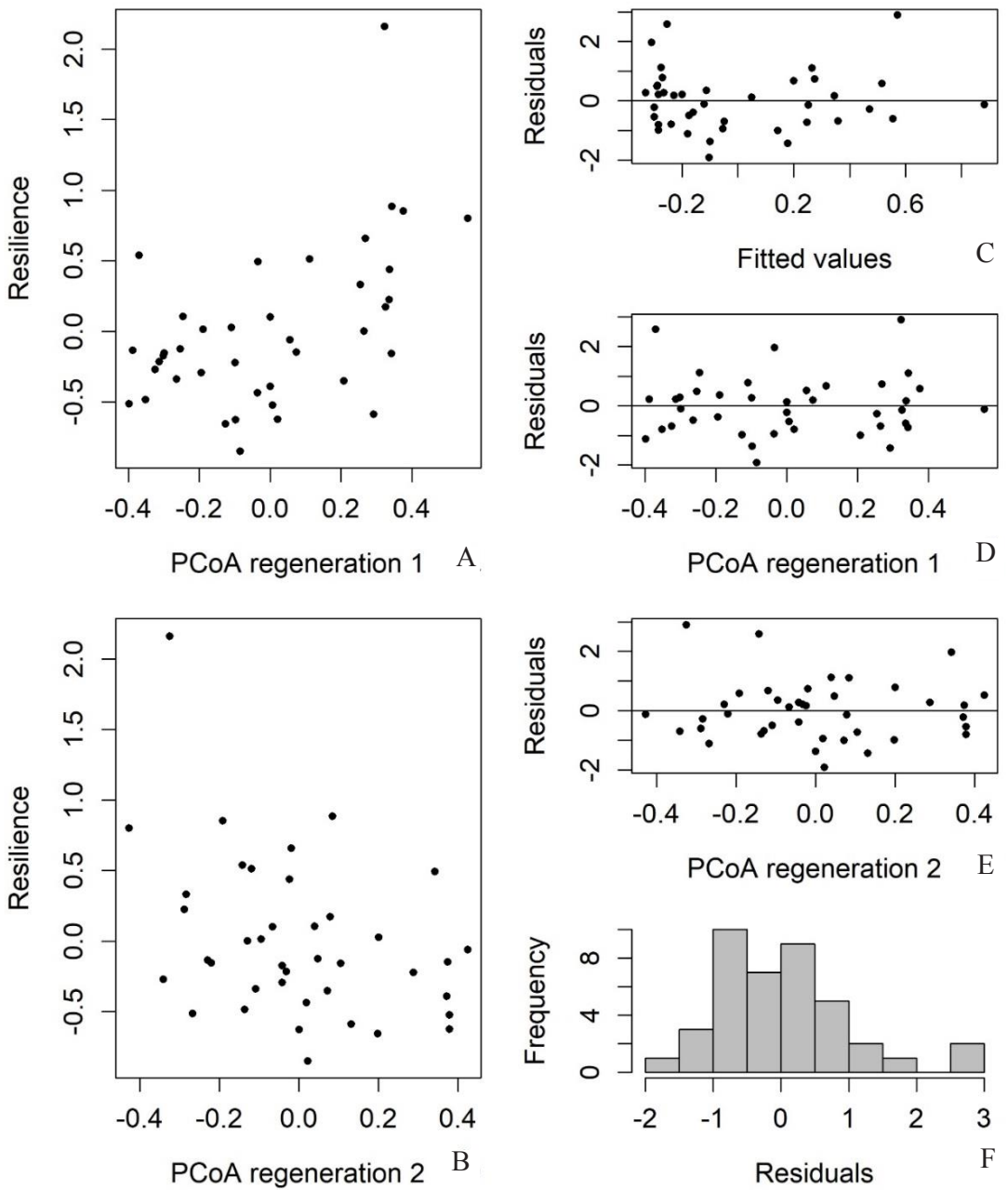

Figure 4. Significant explanatory variables on the successional process speed $[\mathrm{A}=$ Resilience (PCA axis of the regenerative component dynamics rates) $\mathrm{x}$ PCoA axis 1 of the 2014 regenerative component floristic-structural composition; $\mathrm{B}=\mathrm{Resilience}$ (PCA axis 1 of the regenerative component dynamics rates) x PCoA axis 2 of the 2014 regenerative component floristic-structural composition) and residual analysis of the adjusted model $(\mathrm{C}=$ Residual $\mathrm{x}$ adjusted values , $\mathrm{D}=$ Residual $\mathrm{x}$ PCoA axis 1 of the 2014 regenerative component floristic-structural composition; E = Residual x PCoA axis 2 of the 2014 regenerative component floristic-structural composition; $\mathrm{F}=$ Residual frequency], in Upper Montane Araucaria Forest areas, in "Planalto Sul Catarinense" Region, Brazil.

Variables explicativas significativas sobre la velocidad del proceso de sucesión [A = Resiliencia (eje 1 del PCA de las tasas de dinámica de de la regeneración natural) x eje 1 de la PCoA del composición florístico-estructural del componente regenerativo del primer inventario, 2014; $\mathrm{B}=$ Resiliencia (eje 1 del PCA de las tasas dinámicas de de la regeneración natural) x eje 2 del PCoA de la composición florístico-estructural de la regeneración natural del primer inventario, 2014) y análisis de residuos del modelo ajustado $(\mathrm{C}=\mathrm{Residuos} \mathrm{x}$ valores ajustados, $\mathrm{D}=\mathrm{Residuos} \mathrm{x}$ eje 1 del PCA de la composición florístico-estructural de la regeneración natural del primer inventario, 2014; E = Residuos x eje 2 del PCoA de la composición florístico-estructural de la regeneración natural del primer inventario, 2014; F = distribución de frecuencia de los residuos], en áreas del Bosque de Araucarias de Alta Montaña, en "Planalto Sul Catarinense", Brasil.

the second and third authors. To the ICMBio, for the permission to perform this research at São Joaquim National Park, in special to MSc. Michel Omena, for the logistics support of this work.

\section{REFERENCES}

APG IV (Angiosperm Phylogeny Group, DK). 2016. An update of the Angiosperm Phylogeny Group classification for the orders and families of flowering plants: APG IV. Botanical
Journal of the Linnean Society 181(1): 1-20. DOI: https:// doi.org/10.1111/boj.12385

Behling H. 2002. South and southeast Brazilian grasslands during Late Quaternary times: a synthesis. Palaeogeography, Palaeoclimatology, Palaeoecology 177(1-2): 19-27. DOI: https://doi.org/10.1016/S0031-0182(01)00349-2

Brown D. Estimating the composition of a forest seed bank: a comparison of the seed extraction and seedling emergence methods. 1992. Canadian Journal of Botany 70(8): 16031612. DOI: https://doi.org/10.1139/b92-202 
Carlucci MB, LDS Duarte, VD Pillar. 2011a. Nurse rocks influence forest expansion over native grassland in southern Brazil. Journal of Vegetation Science 22(2): 111-119. DOI: https://doi.org/10.1111/j.1654-1103.2010.01229.x

Carlucci MB, FZ Teixeira, FT Brum, LDS Duarte. 2011b. Edge expansion of Araucaria forest over southern Brazilian grasslands relies on nurse plant effect. Community Ecology 12(2): 196-201. DOI: https://doi.org/10.1556/ ComEc.12.2011.2.7

Chazdon RL. 2003. Tropical forest recovery: legacies of human impact and natural disturbances. Perspectives in Plant Ecology, Evolution and Systematics 6(1-2): 51-71. DOI: https:// doi.org/10.1078/1433-8319-00042

Chazdon RL, SG Letcher, M van Breugel, M Martínez-Ramos, F Bongers, B Finegan. 2007. Rates of change in tree communities of secondary Neotropical forests following major disturbances. Philosophical Transactions of the Royal Society B 362(1478): 273-289. DOI: https://doi.org/10.1098/ rstb.2006.1990

Chazdon RL. 2012. Regeneração de florestas tropicais. Boletim do Museu Paraense Emílio Goeldi. Ciências Naturais 7(3): 195-218. Avalilable at http://editora.museu-goeldi.br/bn/ artigos/cnv7n3 2012/regeneracao(chazdon).pdf

Clements FE. 1916. Plant succession. Washington, Carnegie Inst. 512 p. DOI: https://doi.org/10.5962/bhl.title.56234

Collins SL, F Micheli, L Hartt. 2000. A method to determine rates and patterns of variability in ecological communities. Oikos 91(2): 285-293. DOI: https://doi.org/10.1034/j.16000706.2000.910209.x

Connell JH, RO Slatyer. 1977. Mechanisms of succession in natural communities and their role in community stability and organization. The American Naturalist 111(9): 1119-1144. Available at: https://www.jstor.org/stable/2460259?seq=1

Dallabrida JP, AC Silva, P Higuchi, K Souza, R Loebens, LC Rodrigues Junior, VF Soboleski, JG Larsen, FF Walter, RV Kilca. 2017. Elementos nucleadores da paisagem influenciam a dispersão zoocórica em áreas campestres altomontanas. Rodriguesia 68(2): 325-335. DOI: https://doi. org/10.1590/2175-7860201768204

Dallabrida JP, AC Silva, P Higuchi, JG Larsen, GN Santos, CL Lima, LC Rodrigues Junior, FD Machado, AP Cruz, AS Nunes. 2019. Expansão da vegetação arbustiva-arbórea em áreas abertas altomontanas adjacentes a fragmentos florestais, no Planalto Sul Catarinense. Ciência Florestal 29(1): 130-143. DOI: https://doi.org/10.5902/1980509825998

Duarte E, Higuchi P, Silva AC, Sobral MEG, Bortoluzzi RLC, Almeida JA, Larsen JG, Dallabrida JP, Muzeka LM, Aguiar JT, Cuchi T. 2021. Data used in the analyses of "Key factors affecting succession in upper montane forest areas of "Planalto Sul Catarinense" region, Brazil". Accessed 10 Jan. 2021. DOI: https://github.com/higuchip/edilaine_paper bosque

Duarte E, AC Silva, P Higuchi, JG Larsen, DC Ortiz, A Gross, E Turmina, JT Aguiar, MB Vefago, CR Schneider, SF Siqueira, AC Lemos, L Ribeiro. 2018. Sucessão em fragmentos florestais altomontanos no Sul do Brasil: uma abordagem florístico-estrutural e filogenética. Ciência Florestal 28(3): 898-912. DOI: https://doi.org/10.5902/1980509833349

Gleason HA. 1926. The individualistic concept of the plant association. Bulletin of Torrey Botanical Club 53(1): 7-26. DOI: https://doi.org/10.2307/2479933
Hallet L et al. 2020. codyn: Community Dynamics Metrics. Available at: < https://github.com/NCEAS/codyn DOI: https://doi.org/10.5063/F1N877Z6

IBGE - Instituto Brasileiro de Geografia e Estatística 2012. Manual técnico da vegetação brasileira: sistema fitogeográfico, inventário das formações florestais e campestres, Rio de Janeiro: IBGE- Diretoria de Geociências.

Korndörfer CL, LR Dillenburg, LDS Duarte. 2015. Assessing the potential of Araucaria angustifolia (Araucariaceae) as a nurse plant in highland grasslands of south Brazil. New Zealand Journal of Botany 53(1): 5-14. DOI: https://doi.org 110.1080/0028825X.2014.979837

Korning J, H Balslev. 1994. Growth and mortality of trees in Amazonian tropical rain forest in Ecuador. Journal of Vegetation Science 5(1): 77-86. DOI: https://doi. org/10.2307/3235641

Kottek M, Grieser J, Beck C, Rudolf B, Rubel F. 2006. World map of the Köppen-Geiger climate classification updated. Meteorologische Zeitschrift 15(3): 259-263. DOI: https:// doi.org/10.1127/0941-2948/2006/0130

Machado ELM, AT Oliveira Filho. 2010. Spatial patterns of tree community dynamics are detectable in a small (4 ha) and disturbed fragment of the Brazilian Atlantic forest. Acta Botanica Brasilica 24(1): 250-261. DOI: https://doi. org/10.1590/S0102-33062010000100027

Marcílio-Silva V, PO Cavalin, IG Varassin, RAC Oliveira, JMT de Souza, VC Muschner, MCM Marques. Nurse abundance determines plant facilitation networks of subtropical forest-grassland ecotone. Austral Ecology 40(8): 898-908. DOI: https://doi.org/10.1111/aec.12270

Marcílio-Silva V, VD Pillar, MCM Marques. 2016. Functional turnover and community assemblage during tropical forest succession. Community Ecology 17(1): 88-97. DOI: https://doi.org/10.1556/168.2016.17.1.11

Martins KG, MCM Marques, E Santos, R Marques. 2015. Effects of soil conditions on the diversity of tropical forests across a successional gradient. Forest Ecology and Management 349(1): 4-11. DOI: https://doi.org/10.1016/j. foreco.2015.04.018

Meiners SJ, MW Cadotte, JD Fridley, STA Pickett, LR Walker. 2015. Is successional research nearing its climax? New approaches for understanding dynamic communities. Functional Ecology 29(2): 154-164. DOI: https://doi. org/10.1111/1365-2435.12391

Müller SC, Overbeck GE, Blanco CC, de Oliveira JM, Pillar VD.2012. South Brazilian forest-grassland ecotones: dynamics affected by climate, disturbance, and woody species traits. In Ecotones between forest and grassland (pp. 167-187). Springer, New York, NY.

Oksanen J et al. 2016. Vegan: community ecology package. Available at: $<$ http://cran.r-project.org/package=vegan $>$ Acessed in 16 may de 2017.

Pinheiro $\mathrm{J}$ et al. 2016. nlme: Linear and Nonlinear Mixed Effects Models. Available at: http://CRAN.R-project.org/ package $=$ nlme Acessed in 16 May 2017 .

R Core Team. 2019. R: A language and environment for statistical computing. R Foundation for Statistical Computing. Accessed in 20 jun. 2019. Available at http://www.r-project.org

Rocha GPE, DLM Vieira, MF Simon. 2016. Fast natural regeneration in abandoned pastures in southern Amazonia. Forest 
Ecology and Management 370(15): 93-101. DOI: https:// doi.org/10.1016/j.foreco.2016.03.057

Santos HG, PKT Jacomine, LHC Anjos, VA Oliveira, JF Lumbreras, MR Coelho, JA Almeida, TJF Cunha, JB Oliveira. 2013. Sistema Brasileiro de Classificação de Solos. 3. ed. Brasília. SCT-ENBRAPA. 353 p. Accessed in 20 jun. 2019. Available at https://www.embrapa.br/solos/sibcs

Schorn LA, F Galvão. 2009. Dinâmica do estrato arbóreo em três estádios sucessionais de uma Floresta Ombrófila Densa em Blumenau, SC. Accessed in 07 dec. 2019. Cerne 15(2): 221-235. Available at: http://cerne.ufla.br/site/index.php/ CERNE/article/view/207

Sheil D, RM May. 1996. Mortality and recruitment rate evaluations in heterogeneous tropical forests. Journal of Ecology 84(1): 91-100. DOI: https://doi.org/10.2307/2261703

Silva GHM, Overbeck GE. 2020. Soil seed bank in a subtropical grassland under different grazing intensities. Acta Botanica Brasilica 34(2): 360-370. DOI: https://doi.org/10.1590/010233062019abb0297

Silveira TI, LT Maranho. 2012. Avaliação da regeneração natural da vegetação em área recuperada com biossólido. Revista Brasileira de Ciências Ambientais 24: 62-73. Accessed in
07 dec. 2019. Cerne 15(2): 221-235. Available at: http:// abes-dn.org.br/publicacoes/rbciamb/PDFs/24-08 Materia 6 artigos $317 . p d f$

Sühs RB, ELH Giehl, N Peroni. 2018. Interaction of land management and araucaria trees in the maintenance of landscape diversity in the highlands of southern Brazil. PloS One 13(11): e0206805. DOI: https://doi.org/10.1371/journal.pone.0206805

Sühs RB, ELH Giehl, N Peroni. 2020. Preventing traditional management can cause grassland loss within 30 years in southern Brazil. Scientific Reports 10: 783 . DOI: https:// doi.org/10.1038/s41598-020-57564-z

Venables WN, BD Ripley. 2002. Modern Applied Statistics with $S$. Fourth edition. Berlim. Springer. 498 p.

Vieira MS, Overbeck GE. 2020. Small seed bank in grasslands and tree plantations in former grassland sites in the South Brazilian highlands. Biotropica 52(4): 775-782. DOI: https://doi.org/10.1111/btp.12785

Wang Y, U Naumann, ST Wright, DI Warton. 2012. mvabund - an R package for model-based analysis of multivariate abundance data. Methods in Ecology and Evolution 3(3): 471-474. DOI: https://doi.org/10.1111/j.2041210X.2012.00190.X

Recibido: $22 / 11 / 20$

Aceptado: $21 / 10 / 21$ 